\title{
An-Natiq
}

Jurnal Kajian Islam Interdisipliner

Volume 01 Nomor 02 Tahun 2021

e-ISSN: 2777-0176 | p-ISSN: 2798-0200

\section{IMPLEMENTASI SYARAT-SYARAT MUFASSIR DI ERA DIGITAL}

\author{
Setio Budi \\ Universitas IslamNegeri Sunan Ampel Surabaya \\ e-mail: setiobudi66@gmail.com
}

\begin{abstract}
The mufassir terms are a set of rules or ethics codes for those who want to interpret the content of the Qur'an. These requirements relate to a person's personality and the ruler of scientific disciplines, especially interpretation. The presence of digital technology today makes the study of performance develop so rapidly because the study of understanding is no longer through studies, discussions, halaqah, and recitations in mosques but turns into a digital era. Moreover, this paper explained implementing mufassir requirements in the digital age, whether these conditions be applied in the digital era or are the opposite. In this paper, the writer used descriptive analysis using library data. The results showed that implementing the mufassir requirements in this digital era is the same as the qualifications for the mufassir requirements formulated by scholars in general, plus the ability to be technologically literate, including digital technology.
\end{abstract}

Keywords: Interpretation, Mufassir requirements, Digital age

\section{A. Pendahuluan}

Perkembangan ilmu pengetahuan membawa kemajuan begitu pesat bagi peradaban manusia. Salah satunya dengan hadirnya teknologi digital; laptop, komputer, smartphone dan sebagainya. Keberadaan teknologi di atas banyak dimanfaatkan manusia demi kepentingan masing-masing, mulai dari ekonomi, sosial, hingga konten keilmuan. Tulisan ini ingin mengetahui penerapan atau implementasi syarat-syarat mufasir di era digital, artinya bahwa keberadaan teknologi digital oleh sebagian manusia digunakan untuk media menafsirkan AlQur'an dengan cepat dan mudah tanpa harus mempunyai syarat tertentu. Hal ini berbanding terbalik dengan zaman dahulu, bahwa orang yang tidak mempunyai kapasitas dan kapabilitas yang mumpuni dilarang menafsirkan Al-Qur'an , Selain itu menafsirkan Al-Qur'an merupan tugas dan amanah yang berat, karena objek yang di kaji adalah kalam illahi. (Arni, 2013).

Sedangkan menjadi seorang mufassir sangatlah sulit karena banyaknya syarat-syarat yang harus dipenuhi, serta mempunyai keahlian khusus mengenai ilmu-ilmu tafsir. Syarat tersebut digunakan karena akan berdampak pada hasil penafsiran. Namun terlapas dari itu syarat di atas hanya berlaku kepada penafsir yang ingin menafsirkan secara keseluruhan ayat Al-Qur'an . Perlu diketahui bahwa 
syarat-syarat penafsiran ini lahir setelah adanya karya tafsir Al-Qur'an , artinya bahwa di zaman dahulu aturan ini tidak berlaku terlalu ketat, kemudian barulah ilmu tafsir berkembang dan berdiri sendiri pada masa sahabat.

Sepanjang penelusuran penulis setidaknya ada tiga penelitian yang menjelaskan syarat-syarat mufasir, pertama, penelitian Alfurqon tahun 2011, tentang kualifikasi syarat-syarat mufasir serta seberapa penting untuk mempelajarinya. Kedua, Skripsi Siti Hazrotun Halaliyatul Muharromah tahun 2018, penelitian ini menganalisis syarat-syarat mufassir klasik hingga modern dengan berpedoman kitab-kitab ilmu Al-Qur'an . Ketiga, penelitian Imam Mansur tahun 2018, menganalisis syarat-syarat mufasir abad 21, bahwa syarat mufasir merupakan wilayah ijtihad, bentuk kehati-hatian para ulama dan tidak mutlak bisa berubah sesuai tuntutan zaman, salah satu syarat yang arus dimiliki adalah menguasai disiplin ilmu tafsir. Dari ketiga penelitian di atas secara umum menjelaskan syarat-syarat mufasir baik klasik hingga kontemporer serta seberapa penting mempelajarinya, kaitanya dengan era digital belum banyak di bahas. Berangkat dari latar belakang tersebut, tulisan ini secara khusus menanyakan bagaimana syarat-syarat mufassir di era digital, dengan hadirnya era digital apakah ada keharusan menguasai syarat-syarat tersebut. Selain itu bagaimana implementasi syarat-syarat mufasir di era digital.

\section{B. Kualifikasi Syarat-Syarat Mufassir}

Al-Qur'an telah memberi peringatan atau rambu-rambu kepada orang yang tidak memperhatikan isi kandungannya. Hal ini juga pernah dialami oleh para sahabat Nabi, mereka berbeda pendapat atau sering kali tidak mengetahui artinya, namun hal tersebut bisa diselesaikan karena pada saat itu juga para sahabat menanyakan langsung kepada Rasulullah. Selepas Rasulullah tidak ada lagi kemana mereka mengadu tentang persoalan-persoalan mereka menegenai pemahaman kitab suci, dari sinilah timbul perbedaan-perbedaan pemahaman sehingga menghasilkan ragam penafsiran Al-Qur'an .

Ibnu Abbas misalanya, salah satu sahabat dekat Nabi yang paling mengetahui isi Al-Qur'an , membagi tafsir menjadi empat bagian. Pertama, tafsir yang diketahui oleh masyarakat Arab dengan menggunakan bahasa Arab. Kedua, tafsir yang diketahui oleh semua manusia pada umumnya, maka dari itu semua manusia tidak ada alasan untuk memahaminya. Ketiga, tafsir yang diketahui hanya oleh para ulama, ulama disini yaitu ahli tafsir. Keempat, tafsir yang diketahui hanya oleh Allah SWT, berkenaan ayat-ayat yang samar untuk dipahami. (Zarkasi, 1957). Dari penjelasan di atas setidaknya dapat ditemukan pembatasan, pertama pembatasan materi ayat. Kedua pembatasan mengenai syarat-syarat mufassir. Dari segi ayat, bahwa tidak semua ayat bisa dipahami kecuali oleh Allah dan Rasulnya, seperti huruf mukhathaah, muhkam mutasyabih yang terdapat di surat Ali Imran ayat 7. (Suyuti, 1318). 
Penjelasan mengenai syarat-syarat muafassir sebenarnya sudah banyak dijelaskan, namun disini penulis ingin menghadirkan syarat-syarat muafassir secara umum dan singkat sebagai bahan analisis. Al-Qur'an merupakan mukjizat Nabi Muhammad saw. Adapun ayat-ayatnya semua mengandung makna yang sangat luas, maka dari itulah penggunaan bahasa Arab yang tidak mustahil menjadi sebab pilihan menjadi bahasa Aquran ketimbang bahasa lainnya. Perlu diketahui ketika seorang mufassir hendak menafsirkan Al-Qur'an harus memenuhi syarat-syarat dan adab yang berlaku, seorang mufassir harus menguasai banyak disiplin ilmu tentang cara menafsirkan Al-Qur'an . Salah satunnya dengan menguasai ilmu tafsir. Ilmu tafsir merupakan ilmu yang wajib dipelajari sebagai dasar untuk menafasirkan Al-Qur'an , mustahail seseorang mampu menafsirkan Al-Qur'an apabila tidak mengetahui ilmu tafsir.

\section{Syarat-Syarat Berkenaan Pada Pribadi Seorang Penafsir}

Syarat-syarat berkenaan pada pribadi seorang penafsir diantaranya yaitu; mempunyai keribadian yang baik, jujur, lapang dada, tekun beribadah, kesehariannya dihiasi dengan membaca Al-Qur'an serta mempunyai aqidah yang baik. Selain itu mempunyai semangat dan niat yang lurus hanya kepada Allah. Bersikap hati-hati ketika menjelaskan ayat sekiranya sulit untuk dipahami. Mempunyai pengetahuan dan wawasan yang luas tentang ilmu agama, selain itu harus menguasai teknik penulisan, tata bahasa, agar terhindar dari kesalahan yang tidak diinginkan. (Qattan, 2011). Adapun aspek lainya berkenaan kepada kepribadian soarang mufassir yaitu mempunyai ahlak al-Karimah, baik secara ruhaniyah ataupun keseharianya. Dari aspek inilah bahwa dasar seorang mufassir bisa menjelaskan maksud-maksud firman Allah dan tidak terkungkung dari niat jelek dari hawa nafsunya, sehingga pesan kitab suci bisa dipahami kepada seluruh manusia. Ulama terdahulu (ahli tafsir) menempatkan ahlak alKarimah ini sebagai salah satu adab-adab muafassir.

Sementara itu Imam al-Thabari dalam tafsirnya memberikan pedoman adab-adab seoarang mufasir sebagai berikut " hal yang harus diketahui diantara sekian syarat mufassir yaitu mempunyai aqidah yang lurus serta mempunyai kesungguhan terhadap agamanya. (Tolchah, 2016). Imam Jalaluddin al-Suyuti dalam tafsirnya juga mengatakan "perlu diketahui bahwa seseorang tidak akan bisa memahami isi kandungan Al-Qur'an serta rahasia dibaliknya, sementara di dalam hatinya masih ada rasa sombong, cinta dunia, banyak melakukan maksiat, selalu mengikuti hawa nafsunya serta imannya lemah, kemudian sering menggikuti pendapat penafsir yang tidak memiliki ilmu yang mengarah kepada akalnya. Hal inilah yang menjadi penghalang (tabir) dalam mengungkap rahasia makna Al-Qur'an ". (Tolchah, 2016). 
Dari perkataan Imam Jalaluddin al-Suyuti tersebut, Ahmad Bazawy alDhwy membuat pedomann singkat mengenai adab-adab seorang mufassir yaitu; Pertama, niat yang lurus semata karena Allah. Kedua, mempunyai aqidah yang kokoh. Tiga, tidak mengikuti hawa nafsunya. Empat, bersikap tawadu dan tidak sombong. Lima, tidak cinta dunia, Enam, sikap hati-hati terhadap perkara yang tidak jelas, baik perkara yang mengarah ke syariat ataupun keseharian. Tujuh, tidak mengikuti pendapat yang lemah serta pendapat yang dibuat-buat (bid'ah) dalam menafsirkan Al-Qur'an . Delapan, tidak menggunakan akalnya dalam menjelaskan ayat-ayat Al-Qur'an serta menjadikan Al-Qur'an sebagai panutannya. (Suma, 2013).

Manna Khalil al-Qattan dalam kitabnya yang dikutip Amin Suma menyebutkan pedoman yang harus diperhatikan oleh mufassir dalam menafsirkan Al-Qur'an yaitu; Pertama terlalu berani menjelaskan ayat-ayat Al-Qur'an , padahal tidak mempunyai dasar-dasar pokok ilmu yang harus dikuasainya, baik ilmu tafsir serta ilmu pendukung lainnya. Kedua terlalu berani menjelaskan ayat-ayat mutasyabihat, padahal ayat tersebut tidak bisa diketahui kecuali oleh Allah SWT, serta terlalu berani menjelaskan hal ghaib tidak bisa dinalar oleh manusia. Maka dari itu hendaknya mufassir lebih berhati-hati berkaitan dengan hal tersebut. Ketiga terlalu mengikuti hawa nafsu yang berlebihan, dominan mengunakan pendapatnya padahal hal tersebut sangatlah fatal. Keempat menjelaskan ayat hanya untuk mendukung kepentingan kelompok madzabnya, maka hal ini sangat dilarang karena Al-Qur'an bersifat universal untuk seluruh manusia. Selain itu seorang mufassir pasti akan berusaha sekuat tenaga mencari makna ayat dengan segala cara demi membela madzbnya. Kelima, menjelaskan ayat Al-Qur'an dengan menyandarkan bahwa itu maksud Allah, tetapi tidak disertai dalil. Maka hal ini sangat dilarang oleh syariat Agama. (Qattan, 1973).

\section{Macam-Macam Syarat Disiplin Ilmu Untuk Menafsirkan Al-Qur'an}

Sesuai pembangian syarat mufassir, penulis menyimpulkan apabila seseorang ingin menafsirkan kandungan ayat Al-Qur'an secara keseluruhan maka dibutuhkan syarat-syarat sebagai berikut; Pertama, menguasai ilmu bahasa arab dan cabangcabangya. Kedua, menguasai ilmu Al-Qur'an serta cabang-cabangya, menguasai ilmu hadis dan ilmu ushul fiqih. Ketiga, mempunyai pemahaman agama yang mendalam. Keempat apabila syarat-syarat di atas belum terpenuhi maka tidak diperbolehkan untuk menafsirkan Al-Qur'an .

Kemudian Imam Jalaluddin al-Suyuti dalam kitabnya al-Itqan fi< Ulum Qura $>n$ menyebutkan syarat-syarat mufassir sebagai berikut: pertama menguasai ilmu bahasa Arab berserta aspeknya. Kedua menguasai ilmu gramatikal Arab (nahwu-sharaf). Ketiga menguasai ilmu ma>ani, bayan dan badi'. Keempat, 
menguasai ilmu qiroat, baik qiroat $s a b^{\prime} a>h$ maupun asya $>$ rah. Kelima, menguasai ilmu ushul al-Di>n atau ilmu agama dengan sempurna. Keenam, menguasai ilmu ushul fiqih. Ketujuh, menguasai ilmu asbab al-Nuzu>l. Kedelapan, menguasai ilmu nasi>h dan mansu>kh. Kesembilan, Menguasai ilmu fikih dan hukum Islam. Kesebelas, menguasai hadis-hadis Nabi berkenaan penafsiran suatu ayat. Terakhir, mendapatkan 'ilmu al-mawbiha>h, yaitu ilmu yang diberikan oleh Allah kepada hamba yang dikehendaki sehingga bisa berpotensi menjadi seorang mufassir. (Qatthan, 1973).

Selanjutnya Ibnu Taimiyah membuat satu subab mengenai syarat-syarat mufassir yang diberi nama Adwat al-Tafsi>r (perangkat penafsiran). Ibnu Taimiyah membagi syarat-syarat mufassir menjadi lima belas bagian yang harus dikuasai seorang penafsir, diantaranya; ilmu bahasa arab, ilmu gramatikal arab (nahwusharaf), ilmu ushul fiqhi, ilmu qiroat, ilmu ishtiqa $>q$, ilmu ma>'ani, ilmu bayan, ilmu badi', ilmu al-'aqidah, ilmu asbab al-Nuzu>l, ilmu al-qisas, hadis, fiqih, nasi>h mansukh, serta ilmu al mawbihah. (Alfurqan, 2011). Sedangkan Imam al-Dza>habi dalam kitabnya yang berjudul al-Tafsi $>r$ wa al-Mufassiru $>n$ menulis beberapa syarat-syarat muafsir menurut pendapat para sahabat, yaitu; pertama, memahami ilmu bahasa arab seluruh aspeknya, karena dengan ilmu tersebutlah seseorang bisa memahami makna ayat secara baik dan benar. Kedua, mempunyai pemahaman yang baik serta mempunyai pengetahuan yang luas. (Alfurqan, 2011).

Kemudian pada abad berikutnya sebagaian ulama berpendapat; bahwa setiap orang boleh menafsirkan ayat-ayat Al-Qur'an selama orang tersebut menguasai syarat-syarat ilmu yang telah ditetapkan, diantaranya yaitu; ilmu nahwu-sharaf, ilmu asbab al-Nuzul, ilmu qiroat, ilmu nasi>h manu>hk, ilmu balagah dan lain sebaianya. (Alfurqan, 2011). Semantara itu Quraish Shihab memberikan penekanan terhadap orang yang hendak menafsirkan Al-Qur'an , yaitu; menafsirkan ayat Al-Qur'an berbeda dengan berdakwah atau ceramah. Seseorang yang tidak mempunyai kapasitas dan kapabilitas mengenai syarat-syarat mufasir tentu saja boleh menyampaikan ayat-ayat Al-Qur'an, selama penjelasan tersebut masih menggunakan pemahaman para ahli tafsir.

Lanjut Quraish shihab; faktor-faktor yang menjadi penyebab kekeliruan dalam memahami dan menafsirkan ayat diataranya; pertama, terlalu memaksakan pendapatnya untuk memahami suatu ayat atau peran akal lebih dominan. Kedua, kesalah dalam menggunakan metodologi serta kaidah penafsiran. Ketiga, tidak menguasai ilmu bahasa dan gramatikal arab (nahwu-sharaf). Keempat, kesulitan dalam menjelaskan makan ayat, sehingga tidak bisa mengetahui makna tersebut secara utuh. Kelima, dalam menjelaskan ayat Al-Qur'an tidak melihat konteks $a s b a>b$ al-Nuzu>l, munasabah ayat, serta konteks sosial yang ada di masyarakat. Keenam, tidak mengetahui konteks pembicaraan, baik pembicaraan serta tujuan pembicaraan. (Shihab, 1998). 


\section{Imlementasi Syarat-Syarat Mufassir di era digital}

\section{Definisi Implementasi}

Implementasi dapat diartikan sebagai pelaksanaan atau penerapan. (Firdiyati, 2018). Hal ini senada dalam kamus besar bahasa indonesia, bahwa implementasi dimaknai penerapan. Dari sekian banyak literatur implementasi juga dimaknai penerapan atau operasional sesuai aktivitas guna mencapai tujuan atau sasaran, dalam konteks ini yaitu penerapan syarat-syarat mufasir di era digital.

\section{Era Digital}

Perkembangan teknologi yang mengarah ke era digital atau digitalisasi sudah menjadi "kebudayaan", dimana manusia menginginkan sebuah metode atau cara yang kompleks bagaimana merubah sistem yang sulit menjadi gampang, dari sistem manual ke otomatis, dari hal yang rumit menjadi mudah. Selain itu keberadaan era digital merupakan sebuah konsekuensi yang tidak bisa ditolak, maka dari itu tidak ada pilihan untuk menghindar dari era digital. Manusia harus mengambil peran sebaik mungkin agar memberikan banyak manfaat bagi manusia. (Setiawan, 2017).

Kita tahu bahwa tren era digital ini membawa perubahan yang sangat besar, salah satunya ilmu pengetahuan. Manusia serba dimudahkan, kapan saja, dimana saja, bisa mengkases informasi dengan bebas serta menjadi gaya hidup, namun terlepas dari itu di era digital ini juga mempunyai dampak positif dan negatif. Dampak positif di era digital diantaranya; manusia semakin mudah mengakses informasi, tumbuhnya kreatifitas dan inovasi keilmuan dengan media digital, meningkatkan sumber daya manusia dengan pemanfaatan teknologi, tersedianya media dan bahan belajar secara cepat. Adapun dampak negatif di era digital yang harus diantisipasi dan dihindari anatara lain; ancaman dari plagiarisme, menyebabkan manusia berfikir instan dengan mengandalkan internet tanpa mau berfikir kritis, banyak manusia yang menyalahgunakan media dengan kegiatan yang tidak berguna.

\section{Tantangan Kajian tafsir di Era Digital}

Hadirnya teknologi digital sebagai alat untuk mendapatkan suatu informasi nampaknya mampu memberi warna baru dalam kajian keislaman, khususnya kajian tafsir; maktabah syamilah, tafsir web, tafsiralqura.id, dsb. Munculnya media ini nampaknya mampu menjawab kebutuhan masyarakat modern. (Rifai, 2020). Masyarakat semakin enggan membaca kitab-kitab klasik dalam bentuk buku. Maka hadirnya media tafsir di era digital ini bagi masyarakat sudah dipandang cukup untuk menjawab suatu persoalan.

Berangkat dari sini sudah suatu keharusan seyogyanya kajian tafsir harus dikembangkan secara masif di era digital , guna menjaga-melestarikan 
pesan-pesan ilahi sesuai konteks zaman, sehingga kajian Al-Qur'an atau tafsir ini tetap eksis dengan semangat perubahan, tidak abai termakan perubahan zaman. (Mubarok dkk, 2021). Keberadaan cendekiawan, mufassir atau tokoh agama diarapkan bisa ikut andil dalam mengambil peran kajian tafsir di era digital. Karena tuntutan perubahan zaman dan budaya masyarakat modern atas perubahan era digital maka produksi serta konsumsi tafsir bisa digitalisasi. Namun terlepas dari itu bahwa kajian tafsir di era digital mempunyai banyak kekurangan. Adapun kekurangan kajian tafsir di era digital yaitu; pertama, manusia bebas menafsirkankan Al-Qur'an, padahal orang tersebut tidak mempunyai kapasitas keilmuan tentang AlQur'an , terutama ilmu tafsir. Kedua, banyaknya kasus pendakwah ataupun tokoh agama yang berani menjelaskan suatu ayat berdasarkan pemahamanya sendiri atau ngawur, tanpa merujuk pendapat ahli tafsir. Ketiga, kualifikasi mengenai syarat-syarat mufassir tidak berlaku secara ketat. Sehingga hal tersebut sangat berbahaya jika menjadi konsumsi bagi masyarat, maka seyogyanya masyarakat harus selektif dalam hal keilmuan.

\section{Analisis Implementasi syarat-syarat Mufassir di Era digital}

Kemajuan teknologi membawa perubahan besar bagi kajian tafsir di era digital, hal ini tidak menutup kemungkinan terjadinya penyimpanganpenyimpangan, disebabkan karena media yang sifatnya bebas serta tidak ada aturan yang berlaku, maka untuk meminimalisir terjadinya penyimpangan tersebut dibutuhkan aturan, salah satunya dengan menetapkan syarat-syarat mufassir sabagai aturan pokok yang wajib dipelajari.

Setelah memaparkan syarat-syarat mufassir di atas maka dapat diambil benang merah; bahwa implementasi syarat-syarat mufasir di era digital itu sama dengan syarat-syarat mufasir yang telah dirumuskan oleh ulama pada umumnya, khususnya ulama ahli tafsir. Artinya syarat-syarat tersebut merupakan suatu kewajiban yang harus dimiliki seorang mufassir, meskipun konteks sekarang berkenaan pada era digital, apabila seorang yang hendak menafsirkan Al-Qur'an namun tidak mempunyai syarat tersebut, maka orang tersebut dilarang menafsirkan Al-Qur'an, karena berakibat fatal kesalahan pada penafsirannya.

Kaitannya dengan era digital maka dibutuhkan kemampuan melek teknologi. Melek teknologi adalah paham serta mampu menggunakan teknologi dengan baik, termasuk melek teknologi digital. Namun perlu diketahui bahwa kemampuan "melek teknologi” tidak termasuk sebagai syarat-syarat mufassir, maka dari itu untuk menerapkan melek teknologi bisa berkolaborasi dengan ahli teknologi (IT). Adanya kolaborasi tersebut diharapkan pesan-pesan Al-Qur'an bisa dikemas dan bisa disajikan lewat 
bentuk digital. Maka dapat disimpulkan bahwa era digital merupakan jalan atau wadah sebagai terobosan kajian tafsir bisa diterima oleh masyarakat luas sesuai perkembangan zaman, namun tidak lepas dari aturan dan kode etik yaitu menerapkan syarat-syarat mufassir sebagai acuan utama.

\section{E. Contoh Studi Kasus Penafsiran yang Melenceng di Media Sosial}

Penjelasan surat fatir ayat 28

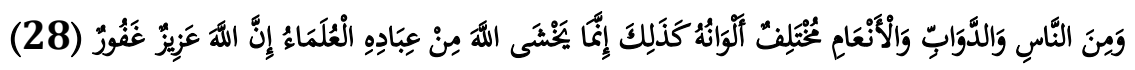

"Dan demikian pula di antara manusia, makhluk bergerak yang bernyawa dan hewan-hewan ternak ada yang bermacam-macam warnanya (dan jenisnya). Diantara hamba-hamba Allah yang takut kepadanya, hanyalah para ulama. Sungguh Allah maha perkasa, Maha pengampun". (Al-Qur'an , 2017)

Kasus pertama mengenai Sugik Nur ketika menjelaskan kandungan surat fathir ayat 28. Hal ini bisa di lihat di laman youtube "karebada" yang dipublikasikan pada tanggal 26 februari 2020. Sebelum menjelaskan ayat tersebut Nur terlebih dahulu bertanya mengenai definisi ulama kepada jamaahnya. Kemudian Nur membacakan surat fathir ayat 28, bahwasannya diantara manusia dan binatang adalah ulama. Lanjut menurut Nur dalam penjelasnya yang diamaksud ulama adalah bisa ular, kambing, ayam bahkan gunung sekalipun yang penting takut kepada Allah. Jadi menurut sugi nur semuanya berpotensi menjadi ulama asalkan takut kepada Allah. Jelas bahwa penjelasan sugi nur di atas sangat melenceng serta menyalahi aturan, maka apabila menjadi konsumsi masyarakat sangat berbahaya.

Muhammad Quraish Shihab, di dalam tafsirnya Al-Misbah memberikan penafsiran dan maksud surat fathir ayat 28 yaitu; setidaknya di dalam surat fathir ayat 28 ini mempunyai dua maksud. Pertama, bahwa ayat ini berbicara mengenai keberagaman dalam kehidupan. Ini bisa dilihat bahwasanya diantara manusia, binatang melata, binatang ternak; kambing, sapi, yang beragam bentuknya, baik ukuran, jenis serta warnyanya. Keberagaman inilah yang menjadi dasar bahwa yang bisa memahami adalah ulama atau orang yang berilmu. Kata ulama sendiri secara bahasa berasal dari kata 'ulama jamak dari kata 'alim. Jadi ulama disini mempunyai pengertian makna mengetahui atau memahami secara secara jelas.

Kedua, bahwasanya orang yang mempunyai pemahaman serta pengamatan terhadap kebaragaman baik alam maupun sosial itu hanya dimiliki oleh ulama. Hal ini kemudian menghasilkan khasyat. Lebih lanjut Qurasih Shihab mengutip pendapat al-Asfahani bahwasanya yang dimaksud khasyat adalah rasa takut yang keluar setelah terjadinya pengamatan atau pemahaman, hal inilah tidak lain yang memiliki hanya ulama selain itu tidak termasuk. Kemudian ayat ini ditutup dengan sifat-sifat Allah maha perkasa serta maha pengampun. Ini bertujuan untuk bahwa Allah tidak butuh kepada hambanya yang tidak beriman dan mesyirikanya, namun 
terlepas itu Allah masih membuka jalan bagi mereka yang menghendaki kebaikan. (Shihab, 2017).

Penjelasan surat Adh-Dhuha> ayat 7

وَوَجَدَكَ ضَالَّا فَهَدَى (7)

"Dan Dia mendapatimu mendapatimu seorang yang bingung, lalu Dia memberikan petunjuk". (Al-Qur'an , 2017).

Kasus kedua mengenai penjelasan evie effendi mengenai surat adh-Dhuha> ayat 7 yang sudah tersebar di media sosial, bahwasanya; "setiap manusia adalah sesat, termasuk Nabi Muhammad". Lanjut evi bahwasanya ketika ada orang yang merayakan maulid Nabi berarti itu merayakan kesesatan Nabi Muhammad. Sebagai klarifikasi hal tersebut maka penulis menggambil penafsiran Quraish Shihab pada tafsir Al-Misbah. Dijelaskan, bahwa secara bahasa kata dhalan berasal dari kata dhalan-yadhillu yang artinya orang yang kehilangan jalan atau kebingungan dalam mengetahui arah. Kemudian kata ini berkemabang menjadi binasa, terkubur, atau secara immateri bermakna sesat dalam hal kebajikan. Dari pengertian tersebut nampaknya banyak orang salah memahami inti surat Adh-Dhuhas ayat 7, bahwasanya "didapati Nabi Muhammad dalam keadaan sesat dan tidak mempunyai agama. Kemudian Allah memberinya petunjuk lewat jalan Agama. Namun hal ini terlihat jelas bahwa pengertian tersebut sangat bertentangan dengan sifat Nabi yang umi serta maksum, terjaga dari segala dosa, maksiat, perbuatan yang tidak terpuji. Lanjut Qurais Shihab menyimpulkan kata dhalan bermakna segala sesuatu yang tidak mengantarkanya kepada kebaikan atau setiap tindakan atau perbuatan yang tidak sesuai dengan kebenaran adalah dhalan. Apabila ingin mengetahui kata dhalan yang cocok dengan ayat di atas maka bisa dilihat dalam surah ayat AshSyu'ra' ayat 52. (Shihab, 2017).

Pelajaran yang bisa di ambil dari contoh di atas adalah; pertama, dalam hal keilmuan khususnya ilmu Agama kita harus selektif mana yang bisa kita jadikan panutan, apalagi di era serba digital. Miris ketika melihat orang yang tidak mempunyai ilmu dengan seenaknya menyampaikan kandungan ayat Al-Qur'an dengan pemahamannya sendiri, mereka bebas mengemukakan pendapatnya lewat media sosial. Kedua, sebagai kontrol keilmuan atas kasus tersebut hendaknya para mufassir, tokoh agama, atau orang berpengaruh mengambil peran agar kesempatan orang-orang seperti itu semakin "sempit" tidak ada celah sedikitpun. Apabila orangorang seperti itu dibiarkan maka akan berakibat fatal, mereka menjelaskan kandungan Al-Qur'an tanpa didasari ilmu.

\section{F. Simpulan}

Seseorang ketika ingin menafsirkan ayat Al-Qur'an secara keseluruhan maka dibutuhkan syarat-syarat sebagai berikut; Pertama, menguasai ilmu bahasa arab 
berserta cabang-cabangnya. Kedua, menguasai ilmu Al-Qur'an beserta cabangcabangnya, menguasai ilmu hadis dan ilmu ushul fiqih. Ketiga, mempunyai pemahaman agama yang kuat dan mendalam. Keempat apabila syarat-syarat di atas belum terpenuhi maka tidak diperkenankan menafsirkan Al-Qur'an .

Impelementasi syarat-syarat mufasir di era digital ini sama saja dengan kualifikasi syarat-syarat mufassir yang telah dirumuskan oleh ulama terdahulu. Kemudian ditambah kemampuan melek teknologi, termasuk melek teknologi digital. Namun, melek teknologi disini tidak termasuk dalam syarat-syarat mufassir. Hadirnya era digital dalam kajian tafsir merupakan wadah dan jalan, agar cakupan kajian tafsir semakin luas. Selain itu untuk menerapakan teknologi digital maka perlu adanya kolaborasi dengan ahli IT.

\section{Daftar Rujukan}

Alfurqon, (2011) "Kaidah Kualifikasi Intelektual Mufasir dan Urgensinya”, Muttawatir: Jurnal Keilmuan Tafsir Hadis Vol. 1 No. 2. (Desember).

al-Qattan, Manna> Khalil. (1973). Ma>ba $>$ his fi $>$ Ulu>m Alqura $>$ n. Beirut: Masyurat al-Ashr al-Hadi>s.

al-Qattan, Manna> Khalil. (2011) Studi Ilmu-Ilmu Al-Qur'an, Terj. Mudzakir, cet 14. Bogor: Pustaka Lintera Antar Nusa.

al-Su>yuti, Jalal al-Di>n. (1318). al-Itqa>n fi> 'Ulu>m al-Qura>n. Mesir: al-Azhar. al-Zarkasi, Badr al-Di>n. (1957). al-Burha>n fi> 'Ulum al-Qura>n. Mesir: al-Halabi. Amin Suma, Muhammad. (2013). Ulumul Quran. Jakarta: PT Raja Grafindo Persada. Arni, Jani. (2013). Metodologi Penelitian Tafsir. Pekanbaru: Daulat Riau.

Firdiyanti, Afrida. (2018). Implementasi Manajemen Berbasis Sekolah. Yogyakarta: CV Gre Publising.

Kementerian Agama RI, (2017). Al-Qur'an dan Terjemahnya. MQ Tebu Ireng.

M Fajar Mubarok dkk. (2021). "Digitalisasi Al-Qur'an dan Tafsir Media Sosial di Indonesia, Journal Iman dan Spiritualis, Vol 1 No 1. (Januari-Maret).

Quraish Shihab, Muhammad. (2013). Kaidah Tafsir. Tanggerang: Lentera Hati, 2013.

Quraish Shihab, Muhammad. (1998). Membumikan Al-Qur'an ; Fungsi dan Peran Wahyu dalam Kehidupan Masyarakat. Bandung: Penerbit Mizan.

Rifai, Ahmad. (2020). “Tafsir Web; Digitalization Of Quranic Interpretation And Democration Of Religious Scour In Indonesia", Jurnal At-Tibyan Ilmu AlQur'an dan Tafsir Vol 5 No 2, (Desember).

Setiawan, Wawan. (2017). “Era Digital dan Tantanganya, Seminar Nasional Pendidikan”, eprints.ummi.ac.id. 
Shihab, M. Quraish. (2017). Tafsir Al-Misbah; Pesan, Kesan, dan Keserasian AlQur'an cet 1. Ciputat: Penerbit Mizan.

Tolchah, Moch. (2016). Aneka Pengkajian Studi Al-Qur'an . Yogyakarta: LKIS Pelangi Aksara. 